У,AK 321

ББК 66.03

DOI 10.22394/1682-2358-2019-4-126-132

E.D. Kachurovsky, postgraduate student of the Comparative Politics Department, Moscow State Institute of International Relations (University) of the Ministry of Foreign Affairs of the Russian Federation

\section{FORMATION \\ AND DEVELOPMENT \\ OF THE THEORIES OF FEDERALISM}

The history of the study of federalism in the world literature from the US Founding Fathers' political essays in the "Federalist" and the research within the framework of jurisprudence to the contemporary political science works is considered. The research works related to the correlation between federalism, and decentralization and democracy are analyzed, and classifications of federations are sited.

Key words and word-combinations: federalism, federal structure, decentralization democracy, state.
E.А. Качуробский, аспирант кафедрь сравнительной политологии Московского государственного института международньх отношений (Университета) Министерства иностранньхх дел Российской Федерачии (email: evgenii. kachurovskii@mail.ru)

\section{СТАНОВАЕНИЕ И РАЗВИТИЕ ТЕОРИЙ ФЕАЕРААИЗМА}

Аннотация. Рассматривается история изучения федерализма в мировой литературе начиная с политических эссе отцов-основателей США в «Федералисте» и исследований в рамках юриспруденции и заканчивая современными политологическими работами. Анализируются исследования, связанные с соотношением федерализма с децентрализацией и демократией, а также приводятся классификации федеративных государств.

Ключевые слова и словосочетания: федерализм, федеративное устройство, децентрализация, демократия, государство.

\section{$\mathrm{H}$} протяжении послеАних Авух столетий число федеративных государств возросмо с оАной федерации в 1787 г. (США), Ао 26 сегодня. Аискуссии вокруг этой формы территориального устройства не прекращаются Ао настоящего времени и, по всей видимости буАут продолжаться еще Аолго. Ао сих пор не решен вопрос, является $\Lambda и$ фелерализм более совершенной формой устройства, чем унитаризм. Можно привести примеры как успешных фелераций (США, Канада, Австрахия, Индия и Ар.), так и провамившихся, например, СССР или 
Югославия, не лучшие времена переживает и Бельгия. Вместе с тем некоторые гетерогенные унитарные государства доказали, что они могут сохранять целостность (Великобритания, Испания). Этот вопрос остается актуальным и Аля Российской Федерации.

Начало вылелению федеративной формы правления было положкено в сборнике статей «Федералист», написанному отцами-основателями США Аж. МэАисоном, А. Гамильтоном и Аж. Ажеем в 1787-1788 гг. [1]. П. Кинг пи-

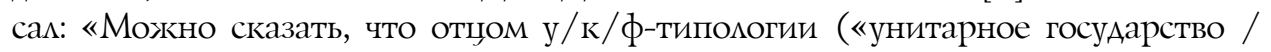
конфедерация / федерация». - Е.К.) был «Федералист» ...» [2]. Поводом к написанию данных программных статей стало составление текста новой Конституџии США. Будучи сторонниками нового государственного устройства, авторы обосновывали преимущества федерации перед конфедерацией. Их аргументацию можно свести к следующим основным положениям. Во-первых, чрезмерно вольные Статьи Конфедеращии (так называлась предыдущая Конституция США от 1777 г.) затрудняли выполнение административных функций и внешних обязательств молодой республики (например, обязательство в срок погасить задолженности внешним кредиторам). Во-вторых, в конфедерации возникала угроза как внутренних междоусобиџ, которые мог обуздать только сильный центр, так и внешнего вторжения, потому что разрозненный союз не мог вести оборону. Наконец, в условиях хаоса и анархии в некоторых штатах местные власти не могли обеспечить права гражАан, что повлекло необходимость вмешательства из центра. В то же время федеративная система, по замыслу авторов, защишала штаты от тирании центра и гарантирова^а им сохранение ряда полномочий.

А. де Токвиць в работе «Аемократия в Америке» $(1835,1840$ гг.) также изучал проблемы федеративного государственного устройства [3] . По мнению ученого, посме победы в войне за независимость исчез внешний враг, который до этого объединял бывшие колонии, а молодая республика нуждалась в восстановлении хозяйства и погашении Аолгов. В связи с этим возникла необходимость централизаџии государственного управления. ОАнако если с определением компетенций центра проблем не возникало (немногочисленные «чрезвычайные полномочия: чеканка монеты, внешние сношения и т.п.), то предметы ведения штатов были куда более многочисленными и разнообразными. Именно поэтому авторы Конститущии США ограничились мишь перечислением сфер компетенџии центра, предполагая, что основные сферы деятельности по умолчанию останутся за штатами. Но поскольку было понят-

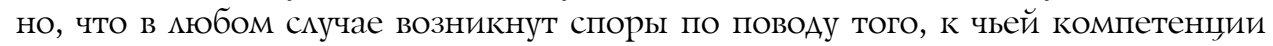
относится та или иная сфера деятельности, Основной закон страны учрежАал Верховный суА, который и домжен был разрешать подобного рода споры [3, c. 101-103].

А. Аайси в работе «Введение в изучение конституционного права» (1885 г.) выделил критерии, отличающие федерализм от унитаризма: разграничение полномочий межАу центром и регионами; верховенство «жесткой» писаной конституџии; раздемение властей; наличие высшего судебного органа, способного отменять законы парламента; отсутствие права на отделение (в отличие от 
конфедерации) [4]. Первый и последний критерии, на наш взгляд, в пояснении не нуждаются, а остальные пункты необходимо разобрать подробнее.

Верховенство "жесткой» писаной конституиии [4, с. 78-81], по мнению А. Аайси, связано с такой ее характеристикой, как сложность внесения в нее поправок законодательным органом по сравнению с принятием или изменением обычного закона. Это дает гарантию регионам, что их автономия, закрепленная в конституции, не будет отменена.

В настоящее время известно, что разделение Властей может существовать и в унитарном государстве. Но в конџе XIX в. оно было кишь в США. Не случайно А. Аайси в Аанном случае противопоставлял Соединенным Штатам Америки Великобританию и Францию, где не существовало разделения властей. Именно это обстоятельство породимо имлюзорную корреляџию, что это явление присуще именно федеративным государствам [4, с. 85-87].

Наличие судебньгх органов, способньх объяһлять неконститучионными законь парламента, тесно связано с предыдущим критерием. Исследуя принщип разделения вмастей, британский ученый главным образом указывал на то, что судебная власть ставится в один ряА с законодательной и исполнительной (например, в Великобритании тех мет независимость судей существовала, но они все равно находились в подчинении по отношению к парламенту и правительству). Он приводил пример британских и французских судов, которые никогда не могми объявлять неконституџионными законы, принятые их парламентами [4, с. хсvхcvii, 87].

Положения А. Аайси развия К. Уэир. Его перу принадлежит работа «Федеративное правление» (1947г.) [5] . Он разработал положения о критериях, отличающих федерацию от унитарного государства. Не упоминая характеристик, не имевших прямого отношения к федерализму, которые А. Аайси относим к федеративным государствам (раздемение властей, верховенство закона и т.п.), политолог добавим новый критерий: процедура Внесения попрабок 6 конституцию должна проводиться при участии как федерального чентра, так и субгектов федераиии.

Следующая важная веха в эволющии теории федерализма связана с труАами У. Райкера. В работе «Федерализм: происхождение, функционирование и значение» он выделял два ключевых условия возникновения федераций: внешнюю военную угрозу и рациональный выбор федерирующихся сторон с целью достижения определенных выгоА [6]. Он утверждал, что из всех федеративных проектов Британии в ее колониях жизнеспособными оказались мишь те, где сушествовали угрозы извне, и практиковался рациональный выбор субъектов федерации. Так, в Канаде раџиональный выбор был обусловлен проблемами преимушественно в франкоязычных Квебеке и Онтарио, а само создание федерации в 1867 г. стало возможным только после гражданской войны 1861-1865 гг. в соседних США, когда появилась внешняя военная угроза. Федерализация Австралии в 1901 г. стала возможной только после активизаџии японской агрессии в Азии и франџузской колониальной политики в Тихом океане. В Индии и Пакистане сушествовала угроза нападения со стороны друг Аруга, что обусловило федералистские тенденџии в этих странах. 
Подобная ситуация возникла и в США в 1787 г., когда на севере стала реальной угроза со стороны Британии.

Главным условием сохранения созданной федерации У. Райкер называл постепенную централизацию государстьа, позволяющую избежать его распада. Так, государственное развитие Швейџарии начиналось как децентракизованная конфедерация в 1291 г.; по Конституции 1848 г. она стала централизованной федерацией, еще более усилившейся по Конститущии 1874 г. Нидерланды начинались как федеративная республика, со временем преобразовавшись в унитарную монархию. США первоначально были конфедерацией, а затем стали федераџией, в которой на протяжении XIX-XX вв. все большее число полномочий переходимо џентру.

Существенный вкмад в развитие теории федерализма внес $\Lambda$. Эмейзер [7] . Он провел классификацию федерализма, выделив несколько его подвидов: собственно федерацию, конфедерацию, федератизм, ассоциированную государственность и квазифедеративные образования. Согласно политологу, федерации обладают центральным правительством, полномочия которому делегируются населением субъектов, а не органами государственной власти регионов. Субъекты федерации обладают правом на самоуправление. Аля роспуска федерации необходимо согласие всех или большинства ее составляющих единиц. По А. Эмейзеру, отличие федераџии от конфедераџии заключается в том, что в первом скучае население участвует как в выборах общенаџиональных, так и региональных органов власти, а во втором - Аюди избирают только органы власти своих регионов, а в центре они формируются региональными властями уже без непосредственного участия населения. Наконец, в федерации каждая единиџа может свободно выйти из состава конфедерации.

Р. Уоттс развик систему критериев, отличающих федерацию от унитарного государства [9]. В частности, он добавил такие критерии, как наличие двухуровневой системь органов власти, осуществляющих свои полномочия в отношении граждан напрямую (центральные и региональные органы власти); распределение источников доходов между федеральньим чентром и регионами, которые получают финансовую самостоятельность в реализации своих полномочий; наличе представительства регионов в чентральныхх органах Власти (как правило, реализуется через верхнюю палату парламента); необходимость согласия большинства субгектов федерачии для изменения конституици. Р. Уоттс обновиц также критерий А. Аайси, связанный с верховным судом и в соответствии с которым отличие федеративного государства заключалось в способности его верховного (конституционного) суда объявцять неконституџионными законы парламента. Р. Уоттс, переформулировав это положение, заостриц внимание на том, что конституционный суд призван разрешать споры межАу центром и регионами, как это делается мишь в федерации, а не отменять акты законодательного органа, что характерно и дмя унитарных государств.

В процессе развития теории федерализма сформировалось несколько направлений ее исследования, выработана классификаџия федераџий. Вопрос взаимовлияния федерализма и децентрализаџии, на первый взгляА, преАстав- 
мяется предельно ясным: федерализм тождествен процессам децентрализации. ОАнако уже А. Токвимь подметиц, что по некоторым параметрам США более централизованны, чем, например, унитарные Испания или Франция. Тем не

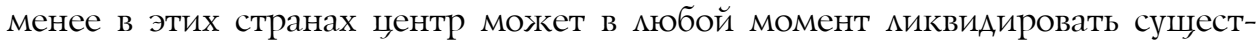
вующие у них элементы децентрализаџии [3, с. 104]. Таким образом, ученый утверждал, что федеративное государство отличается от унитарного не степенью дещентрализации, а сложностью упразднения центром автономии регионов.

Это подчеркивац и А. Аайси, замечая, что ни один из штатов США даже близко не имеет той степени независимости, которой обладает, например, Новая Зеландия в рамках Британской империи. По той же причине франко-канаАцы сохраняли верность империи, опасаясь присоединения к США [4, с. хсvіii] , так как федерация отказывает регионам в независимости и статусе нации [4, c. хсvіiі.]. Именно это положение было выдвинуто А. Аайси в качестве веского аргумента против федерализации Британской империи, означавшей ее централизацию и, соответственно, недовольство в колониях [4, с. сі] .

При выявлении соотношения федерализма и демократии А. Токвияь, изучая США, обратил внимание на их возможную несовместимость. Он отметил, что в нижней палате Конгресса страны количество депутатов обусловлено численностью населения в штатах, а в верхней - установлен равный порядок представительства количества депутатов от каждого штата [3, с. 106] . А. Аайси также подчеркивац, что это препятствует Аоминированию субъекта-гегемона, если таковой имеется [4 с. хсіiі-хсіv].

В. Райкер полагал, что фелерализм защищает граждан от произвола центра и предохраняет демократию от вырождения в охлократию и популизм, но признавац, что при федеративной системе в регионах права граждан могут ограничиваться, при этом центру сложно их защищать [10, с. 53]. В качестве примера приводилось ущемление прав афроамериканского населения в южных штатах США Ао отмены рабства.

А. Пшеворский отмечал, что при демократическом транзите в федерациях этот процесс осложняется отнесением многих сфер политики к компетенџии регионов; в унитарном же государстве повестка дня едина, неделима и открыта $[11$, с. $47-63]$.

А. Степан вылелил еще два фактора, сдерживающих демократизацию. Во-первых, Конституционный суа, роль которого в федераџиях весьма значительна, не явцяется демократическим государственным органом, так как его чиенов никто не избирает. Во-вторых, ограничивающим фактором верхней палаты явцяется объем полномочий, передаваемых в ее ведение. Чем их больше, тем больше она ограничивает демократию. Политолог отмечал также уровень сконцентрированности политической власти в руках регионов. Она измеряется количеством вопросов, решение которых требует квалифицированного большинства в обеих палатах парламента. Чем их больше, тем выше Аемосо-ограничивающая роль федеращии.

Первая попытка кмассификации федераций была предпринята А. Экейзером. Он выделил три теоретические модели федерализма: американскую, 
канадскую и швейцарскую [12, с. 38-42] . В американской модели государственный суверенитет принадлежит народу, который собственно и делегирует его часть центральным и региональным органам власти. Швейцарская модель основана на этнических разцичиях между регионами. Канадская модель тожке связана с межээническими различиями, связанными с проблемой франкофонов. Кроме того, в Канаде федеративная политико-правовая система коррелирует с парламентской Аемократией.

А. Степан подраздемяет федерации на симметричные (Германия, Австрамия, США, Испания, Бразиция и др.) и асимметричные (Индия, Бельгия, Канада, Россия). В отличие от симметричных субъекты асимметричных федераций имеют разный объем прав [8, с. 21-22]. Политолог размичает также федерации «сходящиеся» («coming-together», созданные снизу - США, Швейцария) и «удерживающие» («holding-together», созданные сверху - Индия, Бельгия, Испания) [8, с. 22-23]. Первые федерации были созданными снизу, поэтому на первых этапах изучения проблемы порфедеративные государства рассматривались только как образованные в результате объединения нескольких ранее независимых стран. По мнению А. Аайси, федерация включает в себя определенную «группу государств, которые хотят союза, но не хотят единства» (в оригинале была использована непереводимая игра слов: «...desire union and do not desire unity») [4, с. хсіii]. Схожкего определения придерживались К. Уэир и В. Райкер. Третий вид федеращий - «скмадывающие» («putting-together»), когда регионы объединяются в федераџию в результате их завоевания (СССР), выдемен А. Степаном [8, с. 23] .

А. Степан подразделил федерации на демосо-устанавцивающие («demosenabling») и Аемосо-ограничивающие («demosconstraining»). К первому виду он отнес страны, где федерализм не препятствует демократии (Индия, Германия, Австрия, Бельгия), ко второму - страны, где эта система препятствует ей (США, Бразилия) [8, с. 23-30].

Согласно кмассификаџии А.И. Подберезкина, имеются шесть основных типов федерации: западноевропейский (Германия, Швейцария, Бельгия, Австрия и «полуфедеральные» Испания, Великобритания, Италия и Финляндия); североамериканский (США, Канада, Австралия); матиноамериканский (Аргентина, Бразилия, Мексика, Венесуэла); островной (Сент-Киттс и Невис, Коморские острова, Микронезия); афро-азиатский (Малайзия, Индия, ОАЭ, а также ЮАР); нигерийский (Нигерия, Пакистан, Эфиопия и Мьянма) [13] . Первые три типа включают в себя «старые» федерации, три последних - «момодые». Ава американских типа охватывают «переселенческие» страны, не связанные с этническими разцичиями. Федерации островного, катиноамериканского, и нигерийского типов были созданы в результате деколонизации или краха империй, в состав которых они входили. Ава последних также характеризуются высокой центрацизацией власти. Кроме того, эти два типа, а также островной тип отличаются асимметричностью. Федерации афро-азиатского, матиноамериканского и нигерийского типов были созданы «сверху». Особо А.И. Подберезкин выделяет «постсоциалистический» тип, куда относит Россию и бывшую Югославию. Их специфическими отмичиями он считает этнический характер и асимметричность. 
Таким образом, понятие федерализма возникло еще в XIX в. и постоянно менялось и дополнялось. Сегодня наиболее полное его определение дал Р. Уоттс, который перечислил характеристики этой формы территориального устройства:

1) наличие Авухуровневой системы органов вцасти, которые осуществцяют свою власть в отношении граждан напрямую (органы центра и регионов);

2) разделение между законодательной и исполнительной вмастями и распредемение источников доходов между федеральным центром и субъектами федерации;

3) наличие представительства регионов в центре;

4) наличие писаной конституџии, которую можно изменить только с согласия большинства субъектов федерации;

5) наличие третейского суда, разрешаюшего конфликты между центром и регионами;

6) наличие институтов, обеспечивающих сотрудничество между центром и субъектами в сфере их совместной компетенции.

Аанное определение можно сократить. В частности, представцяется, что пункты 2 и 6 явмяются избыточными и их можкно опустить. Федерализм как таковой не явмяется более совершенной или, напротив, несовершенной формой административно-территориального устройства по сравнению с унитаризмом. Федерация может быть более централизована, чем унитарное госуАарство. Вместе с тем она способна как препятствовать демократии, так и развивать ее.

\section{Библиографический список}

1. Федералист: политические эссе А. Гамильтона, Дж. Мэдисона и Дж. Джея / пер. с англ. M., 1994.

2. Кинг П. Классифицирование федераций // Полис. 2000. № 5. С. 6-18.

3. Токвиль А. Демократия в Америке. М., 1992.

4. Dicey A.V. Introduction to the study of the law (LF ed.). Indianapolis: Liberty Fund, 1982. URL: http://files.libertyfund.org/pll/pdf/Dicey_0125_EBk_v7.0.pdf

5. Wheare K.C. Federal government. N.Y.; London: Oxford University Press, 1947.

6. Riker W. Federalism: Origin, Operation, Significance. Boston; Toronto: Little Brown, 1964.

7. Элейзер. Д.Дж. Сравнительный федерализм // Политология: хрестоматия. Москва, 2000. C. 505-519.

8. Stepan A. Federalism and democracy: beyond the U.S. model // Journal of democracy. 1999. Vol. 10, № 4. P. 19-34.

9. Watts R. Comparing Federal Systems. 3rd ed. Montreal: McGill-Queens' University Press, 2008.

10. Riker $W$. Liberalism against populism: a confrontation between the theory of democracy and the theory of social choice. San Francisco: W.H. Freeman, 1982.

11. Przeworski A. Some Problems in the Study of the Transition to Democracy. // Transitions from Authoritarian Rule: Comparative Perspectives. Baltimore: Johns Hopkins University Press, 1986.

12. Elazar D. Exploring Federalism. 2nd ed. Tuscaloosa: University of Alabama Press, 1991. 2006

13. Подберезкин А.И. Международный опыт и особенности российского федерализма. М., 